\title{
Optimization and characterization of trypsin of Labeo rohita from its visceral waste
}

\author{
Batav Charu * and Gothalwal Ragini \\ Department of Biotechnology, Barkatullah University, Bhopal, M.P. India.
}

Publication history: Received on 20 May 2020; revised on 28 May 2020; accepted on 29 May 2020

Article DOI: https://doi.org/10.30574/gscarr.2020.3.2.0041

\begin{abstract}
The disposal of fish visceral waste, is currently posing a major threat to fishery industries and environment. 35\% of the total global catch and $27 \%$ of the landed fish is wasted. The inappropriate disposal of fish waste pollutes ground water and soil (by nitrate leaching), surface water (by eutrophication) and harbors insect/rodent infestations due to release of noxious odor such as indole, sketol, cadavarine, putricine etc. Technical advancement has enabled recovery of valueadded products. Present investigation involved isolation of visceral enzyme from widely consumed freshwater fish Labeo rohita. The enzyme was purified and characterized as trypsin. Among the different precipitating agents chosen cold acetone was found the best. The amidolytic activity of the enzyme using BAPNA substrate was studied. From the Lineweaver-Burk plot the Km and Vmax were calculated. The molecular weight, optimum pH and temperature were 24 $\mathrm{KDa}, 8.5$ and $40^{\circ} \mathrm{C}$, resp. The LCMS studies showed that the enzyme exhibited $19.3 \%$ similarity with commercial (bovine) trypsin. It was thus, anticipated to minimize the waste burden in an eco-friendly manner.
\end{abstract}

Keywords: Fish visceral waste; Protease; Trypsin; SDS-PAGE; LCMS; Enzyme kinetics

\section{Introduction}

The increased demand for seafood throughout the world has contributed to a rapid growth of aquaculture than any other segment of animal culture industry. Fishes are next only to meat and poultry as a staple food of most of the countries. Aquaculture has thus become an important activity in many countries which contributes to $25 \%$ of the total world seafood supply [1]. By the year 2025, generation of solid waste is expected to reach 19 billion tones. The developing countries are bound to use polluted water for irrigation [2]. According to World Bank report, by 2030 the global fish supply is estimated to increase by 5 lac metric tons. Of this, only 4 lac metric tons will be consumed and remaining will be wasted. This waste includes by-catch discards and processing wastes. The bycatch include non-targeted organisms such as juvenile fishes, marine benthic mammals etc. whereas, processing waste includes head, frames, fins, tails, viscera, and skin [3]. The wastes generated through processing of fish, is around $30-60 \%$ [4]. The global fish production and consumption in the last six years as given by FA0 [5] emphasize over increase in waste production.

The dumping of this waste into sea is very unscientific practice [6, 7]. Waste present in water body undergoes decomposition and generates toxic by-products. This decreases dissolved oxygen and pH and overloads nitrogen, phosphorus and ammonia content i.e. leads to eutrophication. This in turn promotes biomass of planktons [8].Also, improper storage, handling and disposal practices of this waste causes environmental and health problems, insect/rodent infestations and noxious odor such as indole, sketol, cadavarine, putricine etc. The establishment of "zero waste" policy by The European Commission has laid obligations on landings and by-catch [9]. These legislations forbid on discards of landings and by-catch back into the sea [10] and emphasize on utilization of fish waste in an organized manner. The fish waste includes fish head, viscera, skin, scales, air bladder, bones, blood, frame liver, gonads, guts, etc. [11]. Fish waste is rich in proteins, amino acids, bioactive peptides, collagen, gelatin, calcium,

\footnotetext{
* Corresponding author: Batav Charu
} 
enzymes, valuable oils, minerals, fats, pigments and flavors [3]. Using biotechnological approaches, value added products can be obtained thereby reducing the waste load on environment. Some of these are collagen, gelatin, fish hydrolysate, fish oil, and enzymes, as described by Rebah and Miled, [12]. Of these, enzymes are the most important one. Among industrial enzymes, hydrolytic enzymes account for $75 \%$ and among hydrolytic enzymes, proteases contribute $59 \%$ of total worldwide sales of enzymes [13].

The fish culture system of India includes Indian major carps (Labeo rohita, Catla catla and Cirrhinus mrigala) and Chinese carps (Silver carp and Grass carp). Of these, Labeo rohita is the fastest growing species so is most preferred species. The percentage of freshly marketed Labeo rohita stock amounts around 30-35\% in three-species culture system, while in six-speciescultureitforms15-20\%.The present investigation focused on isolation and characterization of trypsin from Labeo rohita viscera.

\section{Materials and methods}

\subsection{Sampling}

The fish samples were procured from 4 different fish markets of Bhopal (Banjari fish market, Bittan market area, Kotra Sultanabad fish market and Shahpura fish market). The fishes (identified by an online database FishBase) were adult and healthy, weighing $2 \mathrm{Kg}( \pm 0.5)$ and were collected during post-monsoon and pre-monsoon seasons. The viscera-liver and intestine were immediately kept in an ice-box and transferred to Molecular Biology Laboratory, Department of Biotechnology, Barkatullah University, Bhopal. 100g liver and 100g intestine (Axis LC/GC weighing balance) of each species was excised, washed with $0.8 \%$ saline to remove blood and debris, labeled and stored at $-20^{\circ} \mathrm{C}$ for further use.

\subsection{Preparation of crude enzyme extract}

The crude enzyme extract was prepared according to the method of Simpson and Haard [14]. A 10\% homogenate of liver and intestine was prepared in extraction buffer $(1 \mathrm{mM}$ Tris- $\mathrm{HCl}$ and $1 \mathrm{mM} \mathrm{CaCl} 2 ; \mathrm{pH}$ ) using mortar and pestle. The suspension so obtained was agitated at $200 \mathrm{rpm}$ at $4{ }^{\circ} \mathrm{C}$ for $30 \mathrm{~min}$ (ORBITEK Orbital shaker, Scigenics- Biotech) followed by centrifugation (Eppendorf Centrifuge, $5415 \mathrm{R}$ ) at $11,400 \mathrm{~g}$ at $4{ }^{\circ} \mathrm{C}$ for $30 \mathrm{~min}$. The supernatant was collected and stored as Crude Enzyme Extract in deep freezer (Blue star) at $-20^{\circ} \mathrm{C}$. Protein concentration was determined by Lowry's method [15] using bovine serum albumin (BSA) as standard.

\subsection{Clarification of crude extract}

The crude enzyme extract was clarified using ice-chilled acetone (1:3), TCA: Acetone (1:3) and ammonium sulfate (30\% and $80 \%$ saturation). After adding precipitant it was incubated for $15 \mathrm{~min}$ at $-20^{\circ} \mathrm{C}$ and centrifuged at $6,000 \mathrm{~g}$ at $4{ }^{\circ} \mathrm{C}$ for $30 \mathrm{~min}$. The supernatant was discarded and pellet was retained. The ammonium sulfate soluble fraction was dialyzed overnight using eggshell membrane (SPINOT magnetic stirrer) against the extraction buffer at $4^{\circ} \mathrm{C}$ to remove excess salt $\left(\left(\mathrm{NH}_{4}\right)_{2} \mathrm{SO}_{4}\right)$.

\subsection{Purification using gel filtration chromatography}

To prepare DEAE-cellulose column $(0.5 \times 5.5 \mathrm{~cm})$, the gel matrix was swollen completely in extraction buffer. An equal volume of buffer was added to the swollen gel to make slurry. This slurry was poured into the column to completely fill it. The column was then washed 2-3times bed volumes of buffer to equilibrate the column and sample was applied (0.25 $\mathrm{ml} \mathrm{min}-1$ ) onto the column. Same buffer was used as effluent and all fractions were collected until the effluent had no detectable absorbance at $280 \mathrm{~nm}$. The fraction with highest absorption peak was chosen for further studies.

\subsection{Characterization of trypsin}

The amidase activity of purified trypsin was determined according to the method of Erlanger et al., [16] using N- $\alpha$ benzoyl-DL-arginine p-nitroanilide (BAPNA) as substrate. $100 \mu \mathrm{l}$ of enzyme sample was added to an aliquot of substrate BAPNA in tris buffer ( $\mathrm{pH} 8.2$ ) and the release of $p$-nitroaniline (resulting in an increase in absorbance) was measured at $410 \mathrm{~nm}$ after 10 second intervals for $3 \mathrm{~min}$. (extinction coefficient $=8800 / \mathrm{M} / \mathrm{cm}$ ) using spectrophotometer. One BAPNA unit of amidase activity is defined as $1 \mu \mathrm{mol} p$-nitroaniline product formed per min from BAPNA at $25^{\circ} \mathrm{C}$.

$$
U=\frac{\Delta A 410 \mathrm{~nm} /(\min ) \times f \times V}{\eta \times l \times v}
$$


Where,

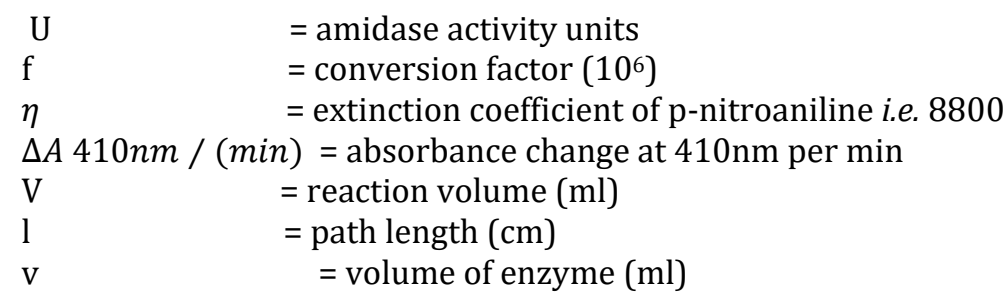

\subsection{Enzyme Kinetics}

On varying substrate concentration, velocity was determined and Lineweaver-Burk double reciprocal plot was constructed. From this plot, $\mathrm{Km}$ and Vmax were determined. The enzyme turnover number ( $\mathrm{k}_{\text {cat }}$ ) was calculated by dividing Vmax by enzyme molar concentration $\left(\mathrm{s}^{-1}\right)$. Using this value, enzyme efficiency was determined $\left(\mathrm{k}_{\mathrm{cat}} / \mathrm{Km}\right)\left(\mathrm{s}^{-}\right.$ $\left.{ }^{1} \mu \mathrm{M}^{1}\right)$.

\subsection{Effect of $\mathrm{pH}$ and temperature}

To determine optimum $\mathrm{pH}$, buffers of varying $\mathrm{pH}$ were prepared: $0.1 \mathrm{M}$ citrate- $\mathrm{NaOH}(\mathrm{pH} 4.0), 0.1 \mathrm{M}$ citrate- $\mathrm{NaOH}(\mathrm{pH}$ 6.0), 0.1 M Tris-HCl (pH 7), 0.1 M Tris-HCl (pH 8.0), 0.1 M Tris-HCI (pH 8.5), and 0.1 M glycine-NaOH (pH 10). To $900 \mu l$ buffer solution, $50 \mu \mathrm{l}$ enzyme sample and $50 \mu \mathrm{l}$ substrate were incubated for $5 \mathrm{~min}$. at $37{ }^{\circ} \mathrm{C}$. After this, $1 \mathrm{ml} 0.1 \mathrm{M} \mathrm{KOH}$ was added to stop the reaction and yellow color produced was measured at $405 \mathrm{~nm}$. The activity was plotted in function of $\mathrm{pH}[17]$.

To determine temperature dependency of sample, $2.8 \mathrm{~mL}$ of the substrate was equilibrated at temperatures of $20^{\circ} \mathrm{C}$ to $70^{\circ} \mathrm{C}$ in a spectrophotometer for approximately $45 \mathrm{~min}$. with $0.2 \mathrm{~mL}$ of the enzyme sample. The rate of hydrolysis was then measured as change in absorbance at $480 \mathrm{~nm} \mathrm{~min}^{-1}[17]$.

\subsection{Molecular weight determination}

SDS polyacrylamide gel electrophoresis (Bio-Rad) was carried out to determine the molecular weight of isolated trypsin [18].

\subsection{Orbitrap High Resolution Liquid Chromatography Mass Spectrometry (O-HRLCMS)}

The enzyme sample was incubated with $50 \mathrm{mM}$ ammonium bicarbonate buffer at $37{ }^{\circ} \mathrm{C}$ for $12 \mathrm{hr}$ to undergo self-cleavage. The solution was desalted using Zip-Tip C18 (Millipore Co., Billerica, MA, USA) and spotted with $\alpha$-cyano-4-hydroxycinnamic acid for peptide finger printing and mass spectrometry.

\subsection{Statistical analysis}

All the values are presented as mean \pm standard deviations carried out in triplicates. The data was analyzed using analysis of variance (ANOVA) and values significant above confidence level $95 \%(\mathrm{p}<0.05)$ were accepted.

\section{Results and discussion}

\subsection{Determination of Protein Content in Crude Enzyme Extract}

A comparative study of protein content among the crude extracts was conducted during different seasons. Among all the fish waste extracted, the protein content was consistently higher in hepatic extracts which may probably due to orientation of liver towards metabolic potential [19]. Generally, protein content of fish tends to be constant with season, but varies due to physiological factors such as starvation, maturation, feeding and spawning [20]. Similar observations were reported by Pilla et al., [21] while determining protein in liver and muscles of Lutjaus johni. Prasad et al., [22] have also observed seasonal variations in composition of biochemical constituents in case of marine fishes Gazza achlamys and Ariomma indica. They stated that hormones exert biochemical fluctuations in fish tissues by stimulating protein synthesis.

\subsection{Clarification of crude extract}


All the precipitating agents were found resourceful as a significant amount of pellet was obtained in each case. Although, ammonium sulfate precipitation method resulted into highest pellet weight $(591.01 \mathrm{mg})$ among all, yet it was found with lower protein content $\left(111.39 \mathrm{mg} \mathrm{ml}^{-1}\right.$ as highest value) than cold acetone precipitation method $\left(133.25 \mathrm{mg} \mathrm{ml}^{-1}\right.$ as lowest value). This may be because of presence of salt particles molecules along with pellet by forming hydrogen bond with precipitated protein molecules as emphasized by Purwanto [23]. Lamas et al. [24] have also reported cold acetone precipitation method effective at initial stage of purification of trypsin from Merluccius hubbsi visceral waste.

\subsection{Purification of Trypsin by Gel Filtration Chromatography}

On performing Gel Filtration Chromatography, all the five fractions gave comparatively narrower peaks which confirm purification of trypsin. However, all the fractions were found to contain trypsin. Appearance of peak around $280 \mathrm{~nm}$ in the crude extract indicates presence of trypsin although along with other proteins, as the peaks were broader as compared to standard (Fig.1).

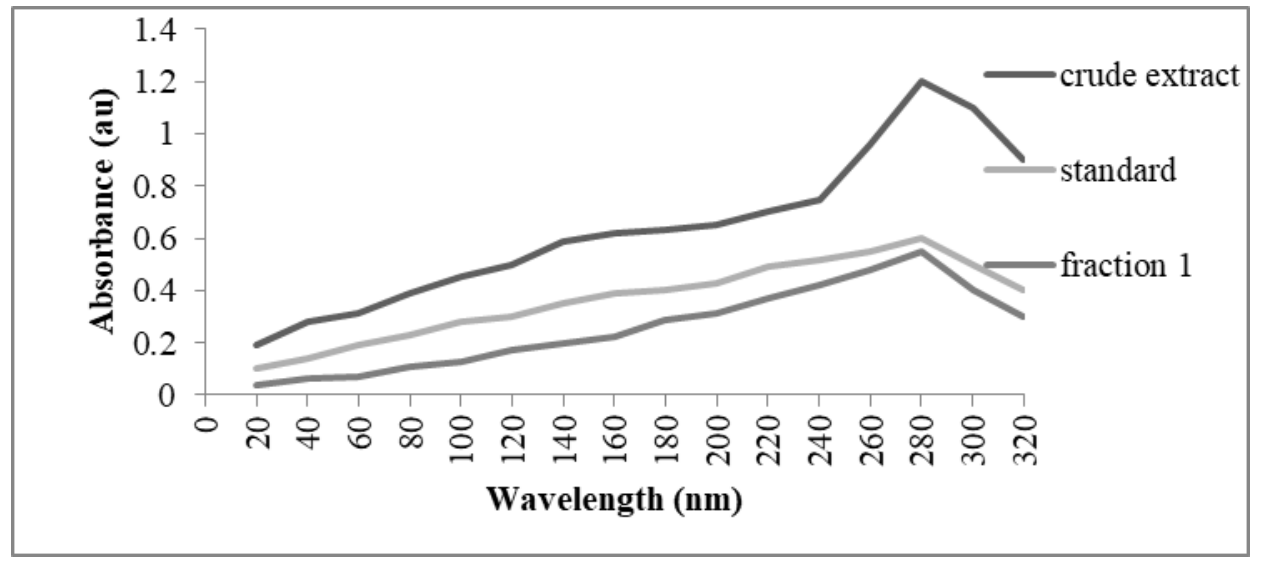

Figure 1 Absorption spectra of crude extract, Standard= commercial trypsin, and Fraction1= chromatographic fraction1

So in order to obtain more yields either all the fractions need to be pooled out together or some other purification technique should be accompanied with the technique performed. The implementation of Sephadex G-100 gel filtration chromatography along with DEAE-Cellulose column chromatography by Geethanjali and Subash [25], for purifying Labeo rohita visceral protease resulted into 13.40 fold purity.

\subsection{Kinetic characteristics of Trypsin in Chromatographic Fraction of RL-IV}

The successful application of an enzyme depends upon its properties such as activity, specific activity, optimum pH and temperature, efficiency, turn over number and other kinetic parameters. In the present study, enzyme activity for BAPNA ( $\mathrm{N}$ - $\alpha$-benzoyl-DL-arginine p- nitroanilide) hydrolysis was studied as $19.56 \mathrm{U} \mathrm{ml}^{-1}$ specific activity as $179.44 \mathrm{Umg}-$ 1. The Km, Vmax and kcat values were $2.47 \mathrm{mM} ; 3.5 \mathrm{~s}^{-1}$ and $0.40 \mu \mathrm{m}^{-1} \mathrm{~min}^{-1}$ as calculated from Lineweaver-Burke plot (Fig.2) using Graph Pad Prism software version8. The enzyme efficiency was found $8.34 \mathrm{~s}^{-1} \mathrm{mM}^{-1}$.

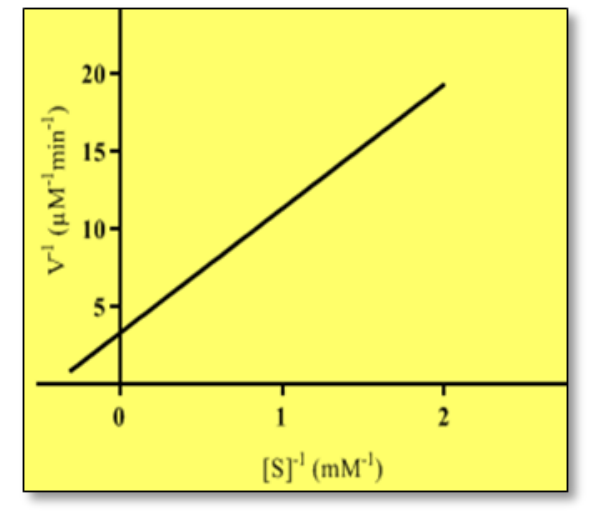

Figure 2 Lineweaver-Burk Plots of fraction RL-IV 
The enzyme activity may be attributed by the herbivore habit of Labeo rohita as emphasized by German et al.[26].They have also suggested that a higher metabolic rate of herbivore fish is responsible for higher trypsin activity. The results of Duarte et al. [27] were however, found contradictory as they observed more hepatic trypsin activity in omnivore than in herbivore. The herbivore feed, being rich in indigestible fibrous cell wall, observes an increased exposure time of the ingest within the digestive tract and thereby contributes to enzyme activity and efficiency.

\subsection{Determination of Optimum pH and temperature}

The effect of $\mathrm{pH}$ on activity of trypsin was studied at a pH range of 4-10 (Fig.3a). Although the activity of trypsin in RLIV at optimum $\mathrm{pH}(8.5)$ was $18.49 \mathrm{U} \mathrm{ml}^{-1}$, yet it retained only $49.2 \%$ activity ( $9.08 \mathrm{U} \mathrm{ml}^{-1}$ ) at pH 10 . Our result was higher than reported Geethanjali and Subash [2]. The genetic features and anatomical locations govern the variation in optimum $\mathrm{pH}$ for different fish species [28]. Presence of enzyme activity at alkaline pH makes the viscera a potential source of enzyme in certain industries (detergent, leather) which employ higher working $\mathrm{pH}$.

The enzyme activity within temperature range $20^{\circ} \mathrm{C}-70^{\circ} \mathrm{C}$ (Fig.3b) was studied and maximum activity was found at $40^{\circ} \mathrm{C}$ which was consistent with the results of Geethanjali and Subash [2]. The enzyme retained $91.1 \%$ activity at $50{ }^{\circ} \mathrm{C}$ and $56.6 \%$ activity at $60{ }^{\circ} \mathrm{C}$ but only $9.8 \%$ activity at $70{ }^{\circ} \mathrm{C}$. The presence of residual activity at higher temperature $\left(70^{\circ} \mathrm{C}\right)$ indicates the thermostable nature of the enzyme which is due to strengthening of hydrophobic interactions and disulfide bonds within the protein molecule [29]. The hydrophobic residues in the enzyme exhibit a tendency to shield themselves from aqueous environment which is thought to impart thermostable nature to the enzyme. The proteases work well as meat tenderizing agent within a temperature range $50^{\circ} \mathrm{C}-70^{\circ} \mathrm{C}$ for the digestion of hard-to-degrade animal proteins. Detergent solution undergoes higher temperature exposure (around $50^{\circ} \mathrm{C}$ ) for longer durations. The protease to be applied as detergent should be compatible with it and tolerate such temperature [30]. Similarly, Aissaoui et al., [31] found the optimum temperature of visceral trypsin of Scopaena notatum as $40^{\circ} \mathrm{C}$. The presence of Ca ${ }^{2+}$ in the extraction buffer employed in this study is thought to have contributed towards thermostability of the enzyme as Ca ${ }^{2+}$ is a known classical trypsin activator [32]. The enzyme retained $91.1 \%$ activity at $50{ }^{\circ} \mathrm{C}$ and $56.6 \%$ activity at $60{ }^{\circ} \mathrm{C}$ but only $9.8 \%$ activity at $70^{\circ} \mathrm{C}$.

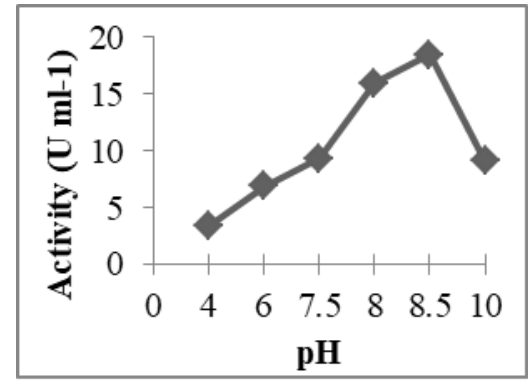

(a)

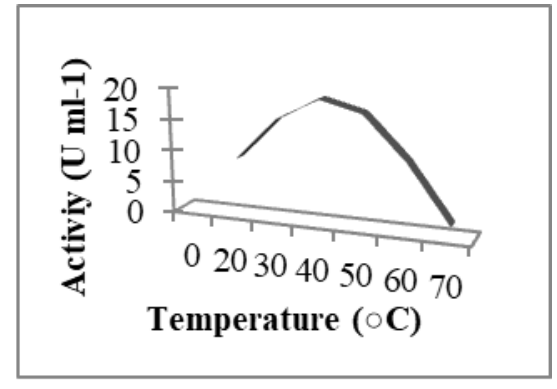

(b)

Figure 3 (a) showing optimum pH for RL-IV, (b) showing optimum temperature for RL-IV

\subsection{Determination of Molecular weight}

From the Electrophoretogram (Fig.4), the molecular weight of enzyme was found $24 \mathrm{KDa}$, in accordance with the findings of Aissaoui et al. [31] who also found similar results while isolating protease from visceral waste of Scorpion fish- Scorpaena notata. Instead of a fixed value the molecular weight falls within a range because of genetic variations among species of different habitat and geographical locations [33]. 




Figure 4 Electrophoretogram of RL-IV (lane2) running along with protein marker (lane1)

\subsection{Analysis of Peptides by Orbitrap High Resolution Liquid Chromatography Mass Spectrometry (O-HRLCMS)}

From the Total Ion Current Chromatogram of RL-IV (Fig.5), the peptides showing resemblance with commercial trypsin were analyzed by spectrophotometer in terms of their $\mathrm{m} / \mathrm{z}$ value. Their sequences are shown in table 1.

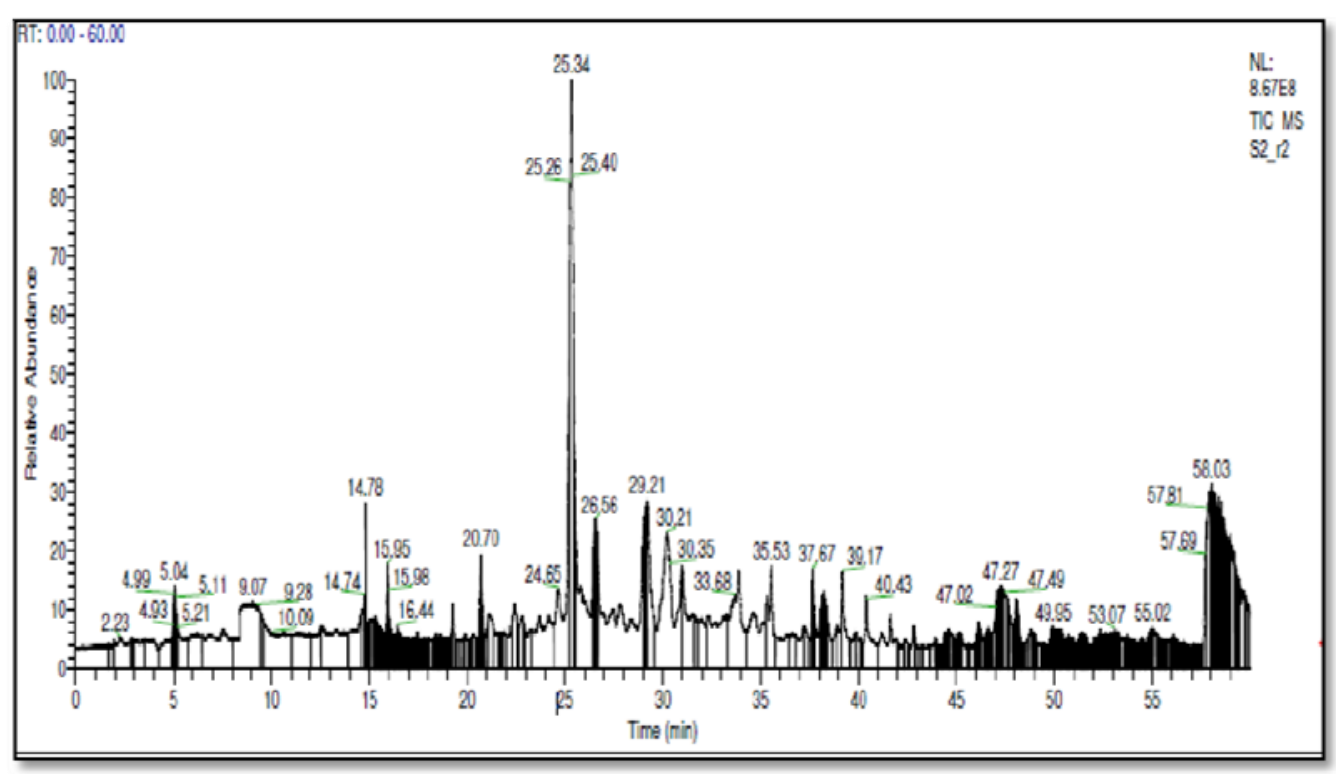

Figure 5Total Ion Current Chromatogram of RL-IV

Table1 Determination of Peaks Obtained from Digest of RL-IV Fraction

\begin{tabular}{lll}
\hline S. No. & Retention time (min) & Sequence \\
\hline 1. & 13.93 & VRLGEHNIVVNEGTEQFINSAKVIRHPSYD \\
2. & 14.01 & AAGTKCSVTGWGNTMSPTADSDK \\
3. & 14.07 & CAGYLEG \\
4. & 24.93 & VTGWGNTMSPTA \\
5. & 25.47 & CSNSYPG \\
6. & 27.85 & PILSD \\
7. & 41.63 & NSAKVIRH \\
\hline
\end{tabular}


The sequences when analyzed using BLAST in protein database (PDB) were found to exhibit 100\% similarity with trypsin from other fishes. Table 2 depicts maximum score with these species (with their accession numbers) upon $100 \%$ query coverage.

Table 2 The comparison of maximum score of the sequence of peptides with other fishes resulted from BLAST

\begin{tabular}{lll}
\hline S. No. & Sequence fragment & Fish Species \\
\hline 1. & EGTEQFI (Max. score 26.1) & Lutjanus purpereus (AMW07444.1) \\
& & Papio anubis (XP017811734.1) \\
& & Anabas testidineus (XP026226638.1) \\
& & Scleropages formosus (XP018587676.1) \\
& & Cyprinus carpio (BAL04386.1) \\
2. & YPGMIT FCAGY (Max. score 52.8) & Labeo rohita (AHY00277.1) \\
& & Carrasius auratus (XP026104836.1) \\
& & Danio rerio (NP955899.2) \\
& MFCAGY LE (Max. score 31.6) & Amphiprion ocellaris (XP023119402.1) \\
3. & & Salmo salar (XP014057038.1) \\
\hline
\end{tabular}

The amino acid sequence coverage percentage is a measure for both completeness of proteolysis and analysis efficiency of the peptides. It was analyzed each digest by LCMS to obtain their respective TIC which when subjected to interrogation by MASCOT search engine exhibited 19.3\% resemblance with commercial bovine trypsin (Fig.6).

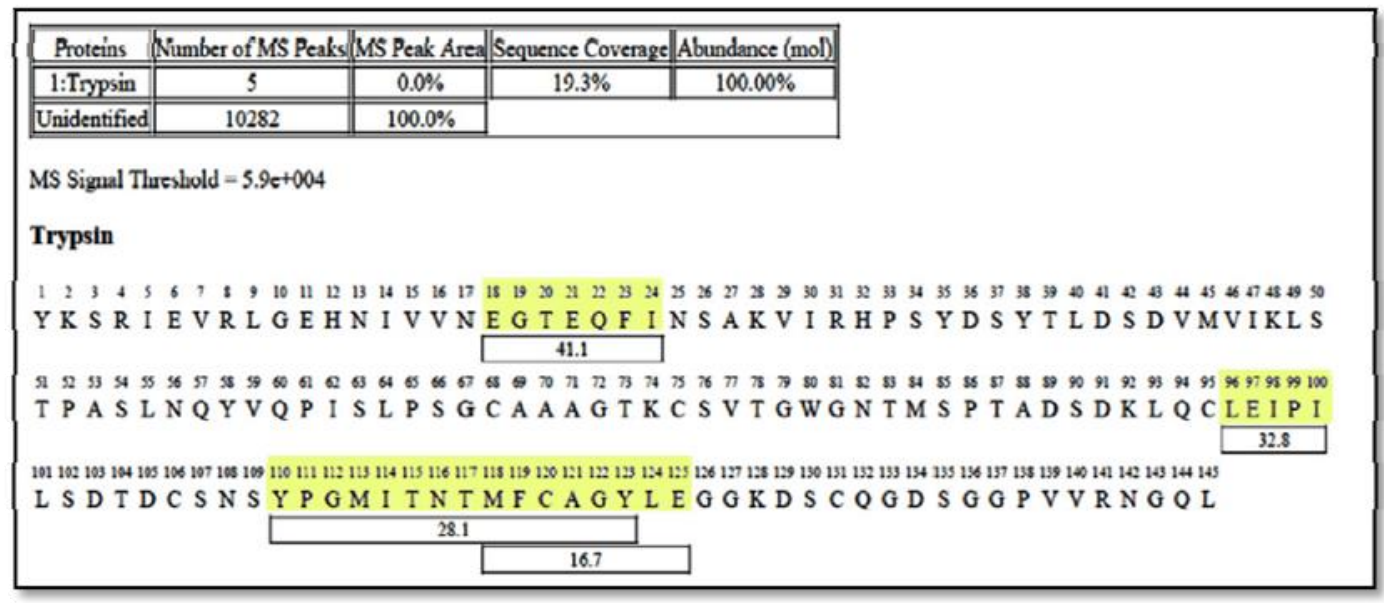

Figure 6 Sequence Coverage Map of digest of RL-IV fraction

Using Bioinformatics tool, BLAST, the enzyme trypsin obtained was found similar to other fish trypsin. The family serine protease is the best characterized enzyme family and thought to have evolved from a common ancestor. Within this family of hydrolases, the enzyme trypsin (3.4.21.4) seems to have been preserved during evolution. Recently, LCMS has been a proven effective analytical technique for detecting common peptides from a protein digest in polychromic fish samples [34]. They identified the peptides generated by digestion of vitellogenin protein isolated from three different fishes -Pimephales promelas, Micropterus salmoides, and Fundulus heteroclitus.

\section{Conclusion}

The visceral trypsin studied showed similar kinetic properties and structural resemblance with other fish trypsin and commercial (bovine) trypsin. This emphasizes over inflation in requirement of thermostable enzyme. Recombinant trypsin has also been produced, but it is quite expensive. On the other hand, the processing of viscera into trypsin could be a practical alternative of waste management. Moreover, the thermostable nature of trypsin can be applied and derivation into hydrolysate can be studied to further valorize the fish visceral waste. Therefore, this study is anticipated 
to solve two purposes firstly, production of industrially important enzymes, secondly, minimization of fish waste in ecofriendly way. On the basis of these findings it can be recommended to fish processing industries to set up a unit in the vicinity of fish catch and landings meant to quickly collect the waste generated.

\section{Compliance with ethical standards}

\section{Acknowledgments}

The author is thankful to the Department of Biotechnology, Barkatullah University, Bhopal, for providing facility for this study.

\section{Disclosure of conflict of interest}

No conflicts of interest.

\section{References}

[1] Srinivasan T and Saranraj P. (2017). Isolation and Identification of spoilage causing microorganisms in an Indian mackerel fish (Rastrelliger kanagurta). International Journal of Advanced Research in Biological Sciences, 4(7), $1-7$.

[2] Geethanjali S and Subash A. (2013). Optimization and immobilization of purified Labeo rohita visceral protease by entrapment method. Enzyme Research, 1-8.

[3] Ramakrishnan V, Ghaly AE, Brooks MS and Budge SM. (2013). Enzymatic Extraction of amino Acids from Fish Waste for Possible Use as a Substrate for Production of Jadomycin. Enzyme Engineering, 2(2), 1-9.

[4] Rajeswari C, Padmavathy P and Anand S. (2018). Composting of fish waste: A review. International Journal of Applied Research, 4(6), 242-249.

[5] FAO. (2018). The state of Food and Agriculture- Migration, Agriculture and rural development, 4.

[6] PNPPRC. (2010). Pollution prevention opportunities in the fish processing industry.

[7] AMEC. (2011). A Report on Management of wastes from Atlantic seafood processing operations.

[8] U.S. Environmental Protection Agency Report. (2010). Washington.

[9] European Commission. (2013). Regulation (EU) No 1380/2013 of the European Parliament and the Council of 11 December 2013 on the Common Fisheries Policy, amending Council Regulations (EC) No 1954/2003 and (EC) No 1224/ 2009 and repealing Council Regulations (EC) No 2371/2002 and (EC) No 639/ 2004 and Council Decision 2004/585/EC.

[10] Jouvenot L. (2015). Utilization of rest raw materials from the fish industry; business opportunities and logistics requirements. Master thesis, NTNU, 10-12.

[11] Guerard F, Decourcelle N, Sabourin C, Floch-Laziat C, Le-Grel L, Le-Floch P, Gourlay F, Le Delezir R, Jaouen P, and Bourseau P. (2010). Recent developments of marine ingredients for food and nutraceutical applications. Journal Des Sciences Halieutique, 2, 21-27.

[12] Rebah FB and Miled N. (2013). Fish processing wastes for microbial enzyme production: a review, Biotechnology, 3, 255-265.

[13] Modilal MRD, Karthikeyan V, Sivakumar K, Magesh R, Karthika VC, Sureshan S, Bhuvaneshwari B, Abarna K and Anand V. (2011). Isolation, Purification and Characterization of proteases from fish waste, International Journal of Institutional Pharmacy and Life Sciences, 1(3), 36-45.

[14] Simpson BK and Haard NF. (1985). Characterization of trypsin fraction from cunner (Tautogolabrus adspersus), Comparative Biochemistry and Physiology, 80(B), 475-480.

[15] Lowry OH, Rosebrough NJ, Farr AL and Randall RJ. (1951). Protein measurement with Folin phenol reagent, Journal of Biology and Chemistry, 193, 265-275.

[16] Erlanger BF, Kokowsky N and Cohen W. (1961). The preparation and properties of two new chromogenic substrates of trypsin, Achives of Biochemistry and Biophysics, 95, 271-278. 
[17] Castillo-Yáñez FJ, Pacheco-Aguilar R, García-Carreño FL, Navarretedel Toro MA and López MF. (2006). Purification and biochemical characterization of chymotrypsin from the viscera of monterey sardine (Sardinops sagax caeruleus), Food Chemistry, 99, 252 -259.

[18] Laemmli UK. (1970). Cleavage of structural proteins during assembly of the head of bacteriophage T4, Nature, $227,680-685$.

[19] Tiwari CG and Pandey VS. (2014). Studies of hematology and histology in Labeo rohita infected with cutaneous columnaris disease, Records of the zoological Survey of India, 114(1), 151-157.

[20] Ravichandran S, Kumaravel K and Pamela Florence E. (2011). Nutritive composition of some edible fin fishes, International Journal of Zoological Research, 7(3), 241-251.

[21] Pilla S, Ratnakala M, Vijaya lakshmi M and Sree Ramulu K. (2014). Biochemical Compositions in Muscle and Liver of Normal and Infected Fish of Lutjanus johni off Visakhapatnam Coast, International Journal of Engineering and Science, 4(9), 38-42.

[22] Prasad SK, Prasad NV and Venkateswarlu Ch. (2017). Seasonal variations in the biochemical composition of muscle and liver of marine fishes, Gazza achlamys and Ariomma indica from Visakhapatnam coast, South India, International Journal of Bioassays, 6, 5407-5414.

[23] Purwanto MGM. (2016).The Role and Efficiency of Ammonium Sulphate Precipitation in Purification Process of Papain Crude Extract, Procedia Chemistry, 18, 127 - 131.

[24] Lamas DL, Yeannes MI and Massa AE. (2015). Partial purification of proteolytic enzymes and characterization of trypsin from Merluccius hubbsi by-products, International Journal of Food and Nutritional Sciences, 4(5), 121130.

[25] Geethanjali S and Subash A. (2018). Isolation and Purification of protease from Labeo rohita viscera, Indian Journal of Biochemistry and Biophysics, 55, 222-226.

[26] German DP, Neuberger DT, Callahan MN, Lizardo NR and Evans DH. (2010). Feast to famine: The effects of food quality and quantity on the gut structure and function of a detritivorous catfish (Teleostei: Loricariidae), Comparative Biochemistry and Physiology - Part A, 155, 281-293.

[27] Duarte S, Paiva MAR, Lara CC, Bemquerer MP and Araujo FG. (2013). Influence of season, environment and feeding habits on the enzymatic activity of peptidase and glucosidase in the gastrointestinal tract of two Siluriformes fishes (Teleostei), Zoologia, 30(3), 296-306.

[28] Vannabun A, Ketnawa S, Phongthai S, Benjakul S and Rawdkuen S. (2014). Characterization of acid and alkaline proteases from viscera of farmed giant catfish, Food Bioscience, 6, 9-16.

[29] Klomklao S, Benjakul S, Kishimura H and Chaijan M. (2011). 24 KDa Trypsin: a predominant protease purified from the viscera of hybrid catfish (Clarias macrocephalus $\times$ Clarias gariepinus), Food Chemistry, 129, 739-746.

[30] Tavano OL, Berenguer-Murcia A, Secundo F and Fernandez-Lafuente. (2018). Biotechnological Applications of Proteases in Food Technology, Comprehensive Reviews in Food Science and Food Safety, 17(2), 412-436.

[31] Aissaoui N, Marzouki MN and Abidi F. (2017). Purification and biochemical characterization of a novel intestinal protease from Scorpaena notata, International Journal of Food Property, 20, 387-395.

[32] Bougatef A. (2013). Trypsins from fish processing waste: characteristics and biotechnological applicationscomprehensive review, Journal of Cleaner Production, 57(15), 257-265.

[33] Khantaphant S and Benjakul S. (2010). Purification and characterization of trypsin from the pyloric caeca of brown stripe red snapper (Lutjanus vita), Food Chemistry, 120(3), 658-664.

[34] He P, Matich EK, Yonkos LT, Friedman AE, Atilla-Gokcumen GE and Aga DS. (2019). Mass spectrometry based detection of common vitellogenin peptides across fish species for assessing exposure to estrogenic compounds in aquatic environments, Science of the total Environment, 646, 400-408.

\section{How to cite this article}

Batav C and Gothalwal R. (2020). Optimization and Characterization of trypsin of Labeo rohita from its visceral waste.GSC Advanced Research and Reviews, 3(2), 39-47. 